\title{
Development of recipe for promoting consumption of Haetsun sprouts and their nutrient evaluation
}

\author{
Hye-Lim Jang $^{1}$, Na-Hyung Kim² ${ }^{2}$ Hee-Jin $\mathrm{Im}^{1}$, Chu-Ja Park ${ }^{1}$, Sang-Cheul Woo ${ }^{3}$, \\ Kyung-Young Yoon ${ }^{1 *}$ \\ ${ }^{1}$ Department of Food and Nutrition, Yeungnam University, Gyeongsan 712-749, Korea \\ ${ }^{2}$ Hanbang Body-Fluid Research Center and College of Oriental Medicine, Wonkwang University, Iksan 570-749, Korea \\ ${ }^{3}$ Department. of Fire Safety Management, Deagu Health College, Daegu 702-722, Korea
}

\section{햇순나물의 소비확대를 위한 조리기술 개발 및 영양성 평가}

\author{
장혜림 ${ }^{1} \cdot$ 김나형 $^{2} \cdot$ 임희진 $^{1} \cdot$ 박추자 $^{1} \cdot$ 우상철 $^{3} \cdot$ 윤경영 $^{1 *}$ \\ ${ }^{1}$ 영남대학교 식품영양학과, ${ }^{2}$ 원광대학교 한방체액조절연구센터, ${ }^{3}$ 대구보건대학 소방안전관리과
}

\begin{abstract}
This study was designed to develop dish recipes using Heatsun sprouts to improve the sprouts' utilization and consumption. We created four kinds of dishes with Heatsun sprouts, including Acanthopanacis cortex, Kalopanax pictus, Aralia elata, and Cedrela sinensis, and analyzed their sensory properties and nutrients. In the sensory evaluation, the overall preference for all the dishes was scored higher than 3.0, Unnaumsun-dakgoginaengchae had the highest score (4.48) among the dishes. Unnamusun-dakgoginaengchae contained higher values of protein; vitamin A, E, and B6; and folic acid than the recommended dietary allowances (RDAs). The recipe for Dureupgokgammuchim was created to reduce the bittemess and the astringent taste of Aralia elata, and it was rich in vitamin $\mathrm{C}$, E, and B6, as well as in folic acid and iron. Ogapisunkkonchijolim was cooked to reduce the fishy smell of a saury with the addition of Acanthopanacis cortex. It contained 1.5 times the protein RDAs, and high levels of antioxidant vitamins, including vitamin $\mathrm{A}, \mathrm{C}$, and $\mathrm{E}$. Chamjugmandu was made by the mixing tofu and various vegetables without adding meat. It had the highest calorie count among the dishes, and its vitamin A, C, and E contents were higher than the corresponding RDAs.
\end{abstract}

Key words : Acanthopanacis cortex, Kalopanax pictus, Aralia elata, Cedrela sinensis, recipe, nutrient analysis

\section{서 론}

음식은 나라와 지역마다 개성과 기호, 지역문화를 대표 할 수 있는 생활양식으로, 관광객의 문화적 경험을 형성하 는데 있어 필수적인 요소이다 $(1,2)$. 특정 관광지를 찾은 관 광객들에게 음식은 즐거운 경험이 되며, 오랫동안 기억할 만한 이미지를 제공하는 중요한 요소로 인정받고 있다(2) 이에 따라 각 지방자치단체들은 음식의 관광 상품화를 위해 지역에서 재배되고 있는 농산물을 활용한 다양한 요리개발 에 노력을 기울이고 있다. 또한, 지역의 특색을 반영한 대표

*Corresponding author. E-mail : yoonky2441@ynu.ac.kr Phone : 82-53-810-2878, Fax : 82-53-810-4768
음식을 관광자원으로 활용함으로써 지역의 발전과 경제 활성화에 기여하고 있다. 이는 지역주민들의 귀속감을 향 상시키며 지역 농산물의 소비를 촉진시키는 데 중요한 역할 을 한다(3)

햇순나물은 그 해에 새로 나고 자란 여린 줄기나 가지를 뜻하는 말로, 흔히 기능성 나무순채라고 불리며 엄나무, 참죽나무, 오가피, 두릅, 화살나무, 다래, 뽕나무 등이 대표 적이다. 이들 햇순나물은 ascorbic acid, retinol, beta-carotene 과 같은 비타민이 풍부하고 $\mathrm{Ca}, \mathrm{K}, \mathrm{P}, \mathrm{Mg}$ 등과 같은 무기질 을 다량 함유하고 있다(4-6). 또한 폴리페놀, 사포닌 및 알칼 로이드 등의 유효성분이 풍부하여 식품 또는 약재로 많이 이용된다(7-9).

두릅나무과(Araliaceae)에 속하는 엄나무(Kalopanax pictus) 
는 가지에 가시가 많으며, 잎은 어긋나고 둥글다. 다른 산채 에 비해 고가이기는 하나 선호도가 높아 재배면적이 넓고, 껍질과 가지, 잎, 뿌리, 새순 등이 다양하게 이용되고 있다. 특히 엄나무의 껍질과 뿌리는 사포닌, 플라보노이드, 페놀 류 및 알칼로이드 등의 유효성분이 많이 함유되어 있어 예로부터 약재로 사용되어 왔으며, 산삼나무 또는 개두릅 이라고 불리는 엄나무의 새순은 식용으로 이용되어 왔다. 엄나무의 새순 또한 껍질과 뿌리, 잎과 더불어 다양한 생리 활성 물질이 함유되어 있어 항산화, 항염증, 항암에 대한 연구 결과가 보고되고 있다 $(10,11)$.

두릅(Aralia elata)은 두릅나무과(Araliaceae)에 속하는 낙 엽관목으로 가지가 많지 않고 줄기에는 날카로운 가시가 있으며, 우리나라뿐만 아니라 일본, 중국 등 아시아 온대 지역에 넓게 분포되어 있다 $(4,6)$. 소비자의 기호도 매우 높 아 소비량이 증가하고 있으며 이에 따라 재배면적 또한 점차 증가하는 추세이다(12). 또한, 두릅나무는 껍질부터 뿌리, 잎, 새순에 이르기까지 다양하게 활용되고 있으며, 특히 새순은 고급 나물로 이용되는 등 약용 및 식용으로 널리 쓰이고 있다(13). 두릅나무의 새순에는 비타민이 풍부 하여 한의학에서는 항산화, 간독성 보호 및 당뇨병 예방에 효과가 있다고 알려져 있다(7).

두릅나무과(Araliaceae)에 속하는 오가피(Acanthopanax cortex)는 오갈피라고도 하며 우리나라와 중국, 러시아에서 도 생산되는 낙엽활엽수다(14). 높은 산 서늘한 음지에 서식 하며 잎, 꽃, 열매, 줄기껍질, 줄기 속, 가지, 새순 등 다양하 게 활용되고 있으나 특히 껍질과 가지, 잎은 약용으로, 새순 은 식용으로 이용된다. 오가피나무의 새순은 잔털이 있으 며, 데쳐서 먹거나 차를 끓여 마시는데 쌉쌀하면서도 뒷맛 이 단 것이 특징이다. 그러나 맵고 쓴 맛이 강하여 호불호가 큰 산채류일 뿐만 아니라 생채로 먹는 것이 어렵기 때문에 장아찌를 만들어 먹는 것이 가장 흔한 오가피순 요리 중 하나로 알려져 있다.

참죽(Cedrela sinensis)은 쥐손이풀목 먹구슬나무과에 속 하는 낙엽교목으로(15) 20-30 m 정도로 곧게 자라며, 성장 이 매우 빠른 식물이다. 예로부터 줄기와 뿌리껍질은 장염, 설사, 혈변에, 열매는 감기 및 관절염에 효과가 있다고 하여 약용으로 사용되었으며, 새순은 나물, 부각 및 장아찌로 먹거나 전을 부쳐 먹는 등 대부분 식용으로 사용되었다. 최근 참죽나무의 새순에 관한 다양한 연구가 진행되면서 새순에 폴리페놀 및 플라보노이드가 다량 함유되어 있고, 항산화활성이 우수한 것이 밝혀져(8) 참죽의 활용 범위가 더욱 광범위해질 것으로 기대된다.

현재 농촌지역의 경제 활성화를 위해 농가에서는 엄나 무, 두릅, 오가피 및 참죽과 같은 햇순나물 단지를 조성하여 소득 증대 및 관광자원화에 힘쓰고 있다. 햇순나물의 재배 면적뿐만 아니라 재배농가가 확대됨에 따라 생산량이 증가 하고 있으며, 지역의 고소득 농가 작목으로 자리잡고 있는
추세이다. 그러나 생채로 소비할 경우 쓴맛과 독특한 냄새 에 대한 거부감으로 식품으로써 인지되지 못할 뿐만 아니라 한정된 조리법으로 소비에 한계가 있다. 따라서 햇순나물 의 소비촉진 및 이용성 향상을 위해 소비자들이 좀 더 친숙 하게 이용할 수 있는 다양한 조리법의 개발이 필요하다. 이에 따라 본 연구에서는 햇순나물의 소비촉진 및 재배 지역의 특색 있는 음식 및 관광 상품의 발굴, 개발에 기여하 고자 햇순나물을 활용한 조리기술을 개발하고 이들의 영양 성을 평가하고자 하였다.

\section{재료 및 방법}

\section{실험재료}

본 실험에서는 햇순나물 4종 즉, 엄나무, 두릅, 오가피 및 참죽을 2013년 4월 중순에서 5월 초 경상북도 상주에서 채취한 8 15 cm 정도의 새순을 구입하여 사용하였다. 각각 의 햇순나물이 물러지지 않는 기간 내에 필요시마다 꺼내어 깨끗한 물에 씻고 재료로 사용하였으며, 기타 부재료는 대 형마트(경산시)에서 구입하여 사용하였다.

\section{요리법 개발}

햇순나물을 활용한 요리의 조리방법은 5 종의 조리서적 (16-19)에 수록된 요리의 식재료 및 분량, 조리법을 참고하 여 무침, 조림 등을 개발하였다. 실험조리를 거쳐 레시피를 결정하고 조리하였으며 세 번의 관능검사를 실시하여 기호 도에 따라 레시피를 보완, 수정한 다음 최종 요리법을 결정 하였다.

\section{영양성 평가}

관능검사로 보완, 수정된 조리법에 의해 조리된 햇순나 물 요리의 영양성 평가는 사용한 생것 또는 건물, 조리된 형태의 식재료 가식부의 중량을 CAN Pro 4.0(Computer

Aided Nutritional Analysis Program ver. 4.0, Korean Nutrition Society, 2010)을 이용하여 산출하였다. CAN Pro 4.0에 수록되어 있지 않은 식품은 유사 식품으로 대체하였 으며, 사용량이 적은 향신료 및 조미료는 열량을 비롯한 영양소에 큰 영향을 주지 않는 분량이므로 생략하였다. 또한 이들의 영양소 함량은 한국인 성인 남자(20-29세) 1 일 권장 량의 $1 / 3$ 을 기준으로 표기하였다(20).

\section{관능검사}

햇순나물을 이용한 다양한 요리의 관능검사는 1점 '매우 싫다'에서 5점 '매우좋다'까지의 5점 기호척도법을 사용하 여 20명의 숙련된 패널에 의해 실시하였다. 평가항목은 외 관, 색, 풍미, 맛, 전체적인 기호도 등 요리의 특성을 고려하 여 작성하였으며, 평가항목별 수용 여부는 평가점수를 기 
준으로 3 점 이상인 경우 수용하는 것으로 하였다.

\section{결과 및 고찰}

\section{엄나무순닭고기냉채}

'엄나무순닭고기냉채' 조리법을 개발하기 위해 각 재료 의 분량과 소스의 첨가량을 달리하여 기호도를 측정한 후 가장 기호성이 우수한 조리법을 결정하였다(Table 1). ‘엄나 무순닭고기냉채' 조리를 위해 첫째, 냄비에 편으로 썬 생강 과 청주를 넣고 끓이다가 닭가슴살을 넣어 익힌 후 결대로 찟는다. 둘째, 엄나무순은 씻어서 물기를 제거하여 $5 \mathrm{~cm}$ 길이로 썰고, 토마토는 껍질과 씨를 제거하고 썰며, 양파는 채 썰어 물에 담가두었다가 건진다. 셋째, 준비한 닭가슴살 과 엄나무순, 토마토, 양파를 골고루 섞은 후 양념장으로 버무린다. 엄나무는 단백질이 풍부한 닭 또는 불포화지방 산이 풍부한 오리와 함께 요리하면 잡냄새를 제거해 줄 뿐만 아니라 닭과 오리의 기름을 흡수하기 때문에 주로 닭 또는 오리 요리에 함께 쓰인다. 또한, 엄나무와 같이 향을 가진 산채류는 식욕을 증진시키고, 소화를 촉진시키 는 등의 효과가 있다. 냉채는 차게 하여 먹는 채로 닭고기, 편육, 새우 등을 계절 채소와 함께 섞어서 무친 음식이다.
칼로리가 낮아서 다이어트에도 도움이 되며, 낮은 칼로리 에 비해 각종 채소와 단백질 급원 식품이 들어가 있어 포만 감을 준다.

따라서 위의 레시피로 조리된 '엄나무순닭고기냉채'는 일반적으로 많이 알려진 닭고기냉채에 닭고기의 동량에 해당하는 엄나무순을 넣어 향을 돋움으로써 엄나무 고유의 쓴맛을 감소시켜 성인뿐만 아니라 어린이의 기호에도 좋을 것으로 판단된다. 또한 대부분 생채소를 사용하기 때문에 열에 약한 비타민의 손실을 최소화하여 부족한 비타민 및 무기질을 보충해줄 것으로 판단된다.

\section{두릅곶감무침}

‘두릅곶감무침' 조리법을 개발하기 위해 각 재료의 분량 과 소스의 첨가량을 달리하여 기호도를 측정한 후 가장 기호성이 우수한 조리법을 결정하였다(Table 1). 먼저, 두릅 을 찬물에 씻어 물기를 제거하고, 곶감과 연근은 각각 채 썰고 편 썰어 끓는 물에 살짝 데쳐낸다. 다음, 바나나는 껍질을 제거하고 으깨며, 매실청과 소금을 넣고 골고루 섞 는다. 두릅과 곶감, 연근을 골고루 섞은 후 으깬 바나나와 함께 버무려낸다. 두릅 순은 소비자들의 기호가 높은 만큼 다양한 방법으로 요리하여 섭취한다. 생으로 먹기도 하지 만 데쳐서 초고추장에 찍어먹거나 소고기와 꼬치에 끼워

Table 1. Recipe of dishes using Haetsun sprouts

\begin{tabular}{|c|c|c|c|}
\hline Haetsun dish & Ingredient & Amount $(\mathrm{g})$ & Cooking methods \\
\hline \multirow{17}{*}{$\begin{array}{l}\text { Umnamusun } \\
\text {-dakgoginaengchae }\end{array}$} & (3 serving sizes) & & \multirow{17}{*}{$\begin{array}{l}\text { 1. Sliced ginger and Cheongju in a pot with water and boil. } \\
\text { 2. Put the chicken breasts into (1) and cook. } \\
\text { 3. Wash Kalopanax pictus sprout and drain the water, and cut into } 5 \mathrm{~cm} \text { lengths. } \\
\text { 4. Remove tomatoes peel and seed, and cut into slices. } \\
\text { 5. Sliced onions soaked in water and bring out of water. } \\
\text { 6. Mix chicken breasts, Kalopanax pictus sprout, onion, and tomato with a sauce } \\
\text { (pineapple, onion, garlic, sugar, vinegar, fermented mustard, and salt). }\end{array}$} \\
\hline & Kalopanax pictus sprout & 200 & \\
\hline & Chicken breasts & 200 & \\
\hline & Onion & 50 & \\
\hline & Tomato & 200 & \\
\hline & Ginger & 20 & \\
\hline & Roasted peanuts & 30 & \\
\hline & Salt & 2 & \\
\hline & Pepper & 2 & \\
\hline & Cheongju & 15 & \\
\hline & Sauce & 10 & \\
\hline & Onion & 50 & \\
\hline & Garlic & 20 & \\
\hline & Sugar & 30 & \\
\hline & Vinegar & 30 & \\
\hline & Mustard & 15 & \\
\hline & Salt & 15 & \\
\hline \multirow{8}{*}{$\begin{array}{l}\text { Dureubgokgam } \\
\text {-muchim }\end{array}$} & (2 serving sizes) & & 1. Wash Aralia elata sprout in cold water, and drain the water. \\
\hline & Aralia elata sprout & 200 & 2. Cut a dried persimmon into fine strips. \\
\hline & Dried persimmon & 120 & 3 Cut lotus root into thinly slice \\
\hline & Lotus root & 100 & 4 Din 2 and 3 into hoiling water for an instant \\
\hline & Sauce & & 4. Dip (a) alla \\
\hline & Banana & 200 & 5. Remove banana peel, and mash. \\
\hline & Apricot syrup & 50 & 6. Add apricot syrup and salt into (5). \\
\hline & Salt & 5 & 7. Mix Aralia elata, dried persimmons, lotus root with a sauce $(5++6)$. \\
\hline
\end{tabular}


두릅적을 지져 먹기도 하고 두릅에 튀김옷을 입혀 살짝 튀겨 먹기도 한다. 그러나 두릅을 생으로 먹으면 쓴맛과 떫은맛 때문에 거부감이 들며, 데치거나 지지거나 튀기면 영양소의 손실을 가져오므로 쓴맛과 떫은맛을 줄일 수 있는 방법을 마련하거나 영양소의 손실을 최소화하여 섭취하는 것이 바람직하다.

따라서 위와 같은 레시피로 조리된 '두릅곶감무침'은 곶 감과 함께 무쳐 두릅의 쓴맛과 떫은맛이 곶감과 연근의 단맛과 어우러짐으로써 기호성이 증가될 것으로 판단된다. 또한 두릅을 생으로 조리하여 섭취함으로써 영양소의 손실 을 막음으로써 두릅의 기능성을 최대한 이용할 수 있을 것으로 판단된다.

\section{오가피순꽁치조림}

'오가피순꽁치조림' 조리법을 개발하기 위해 각 재료의 분량과 부재료의 첨가량을 달리하여 기호도를 측정한 후 가장 기호성이 우수한 조리법을 결정하였다(Table 2). 첫째, 오가피순은 끓는 물에 소금을 넣어 데치고 꽁치는 내장을 제거하고 $5 \mathrm{~cm}$ 길이로 썬다. 둘째, 무는 큼직하게 썰고 대파
는 어슷썰며, 청양고추는 잘게 썰어 준비한다. 셋째, 다시마 물을 넣은 냄비에 무를 넣은 다음 무가 익으면 꽁치와 양념 장을 넣고, 꽁치가 익으면 오가피순과 대파, 청양고추를 넣어 조린다. 위의 레시피로 조리된 '오가피순꽁치조림'은 무와 더불어 향이 나는 산채류인 오가피순을 활용함으로써 꽁치의 비린내를 줄여주고 꽁치에 부족한 비타민 $\mathrm{C}$ 를 보충 해줄 수 있을 것으로 생각된다. 오가피순과 더불어 주재료 로 사용된 꽁치는 고등어와 더불어 등푸른 생선의 대표적인 어류로, 불포화지방산인 eicosapentaenoic acid(EPA)와 docosahexaenoic acid(DHA)의 함량이 높다. 또한 어유에 다량 함유되어 있는 $\mathrm{EPA}$ 와 $\mathrm{DHA}$ 는 혈관을 확장시켜 혈압 을 낮추어주며, 혈중 중성지방과 콜레스테롤을 낮추어 동 맥경화 및 심근경색을 예방한다고 보고되어 있다 $(21,22)$ 그러나 꽁치와 같은 소형 적색육어는 육조직이 연하고 자가 소화효소의 활성이 뛰어나 선도저하가 빠르게 일어나기 때문에(23), 다른 어류에 비해 비린내가 심하여 기호성이 낮은 편이다(24). 따라서 '오가피순꽁치조림'은 오가피의 독특한 맛과 향이 꽁치의 비린내를 완화시키고 음식의 풍미 를 부여시킬 수 있을 것으로 판단된다.

Table 2. Recipe of dishes using Haetsun sprouts

\begin{tabular}{|c|c|c|c|}
\hline Haetsun dish & Ingredient & Amount (g) & Cooking methods \\
\hline \multirow{14}{*}{$\begin{array}{l}\text { Ogapisun } \\
\text {-kkongchijolim }\end{array}$} & (4 serving sizes) & & \multirow{14}{*}{$\begin{array}{l}\text { 1. Blanch Acanthopanax cortex sprout in boiling water and drain. } \\
\text { 2. A saury removes the internal organs and cut into } 5 \mathrm{~cm} \text { lengths. } \\
\text { 3. Cut a radish into thick pieces, cut a green onion into long strips, and cut a hot pepper into small } \\
\text { pieces. } \\
\text { 4. Cook a radish in a kelp soup. } \\
\text { 5. Put a saury and sauce (powdered red powder, sugar, red pepper paste, aged soy sauce, ginger juice, } \\
\text { minced garlic, pepper) into (4) and cook. } \\
\text { 6. Put Acanthopanax cortex sprout, green onion, and hot pepper into (5) and boil down. }\end{array}$} \\
\hline & Acanthopanax cortex sprout & 300 & \\
\hline & Saury & 400 & \\
\hline & Radish & 100 & \\
\hline & Green onion & 20 & \\
\hline & Hot pepper & 12 & \\
\hline & Sauce & & \\
\hline & Powdered red pepper & 60 & \\
\hline & Sugar & 30 & \\
\hline & Red pepper paste & 30 & \\
\hline & Aged soy sauce & 60 & \\
\hline & Ginger juice & 5 & \\
\hline & Minced garlic & 15 & \\
\hline & Pepper & 2 & \\
\hline \multirow{15}{*}{ Chamjugmandu } & (2 serving sizes) & & \multirow{9}{*}{$\begin{array}{l}\text { 1. Knead with wheat flour, salt, sugar, and eggs. } \\
\text { 2. Blanch Cedrela sinensis sprout in boiling water with salt and cut into a small pieces. } \\
\text { 3. Cut a pumpkin into long strips and seasoned with salt, and drain the water. } \\
\text { 4. Wash leek and cut into } 1 \mathrm{~cm} \text { lengths. } \\
\text { 5. Squeeze and mash bean curd. } \\
\text { 6. Mix Cedrela sinensis sprout, pumpkin, leek, bean curd and then seasoned with salt, sesame, and } \\
\text { sesame oil. }\end{array}$} \\
\hline & Cedrela sinensis sprout & 200 & \\
\hline & Bean curd & 100 & \\
\hline & Leek & 100 & \\
\hline & Pumpkin & 100 & \\
\hline & Sauce & & \\
\hline & Salt & 1 & \\
\hline & Sesame & 1 & \\
\hline & Sesame oil & 1 & \\
\hline & Dough & & 7. Roll out (1) with a diameter $7 \mathrm{~cm}$. \\
\hline & Wheat flour & 200 & 8. Put some of the filling mixture (6) into the center of a (7). \\
\hline & Water & 45 & 9. Steam stuffed dumplings for $5 \mathrm{~min}$. \\
\hline & Sugar & 5 & 10. Serve with vinegar soy sauce. \\
\hline & Egg & 15 & \\
\hline & Salt & 1.25 & \\
\hline
\end{tabular}




\section{참죽만두}

'참죽만두' 조리법을 개발하기 위해 각 재료의 분량과 부재료의 첨가량을 달리하여 기호도를 측정한 후 가장 기호 성이 우수한 조리법을 결정하였다(Table 2). 우선 밀가루에 소금, 설탕, 달갈을 넣어 반죽한다. 둘째, 참죽은 끓는 물에 소금을 넣고 데친 후 잘게 썰고, 호박은 채 썰며 부추는 $1 \mathrm{~cm}$ 로 썰어 준비한다. 셋째, 두부는 면보에 싸서 물기를 제거하고 으깬다. 넷째, 참죽에 호박과 부추, 두부를 넣고 골고루 섞어 만두소를 만들고, 반죽한 밀가루를 얇게 펴서 만두소를 넣고 만두를 빚는다. 만두는 밀가루나 메밀가루 반죽으로 피를 만들어 고기와 두부, 각종 채소 등으로 버무 린 소를 넣고 빚어서 삶거나 쪄먹는 음식이다. '참죽만두'는 고기를 넣지 않고 두부와 각종 채소를 넣어 빚었기 때문에 포화지방산의 함량이 적고 단백질, 비타민 및 무기질이 풍 부할 것으로 판단된다.

\section{관능적 특성}

각각의 조리법에 따라 조리된 4종의 햇순요리에 대한 관능검사 결과는 Table 3 과 같다. 햇순요리 4종의 전반적인 기호도가 3.0 이상으로 만족 수준이었으며, 그 중 '엄나무순 닭고기냉채'의 기호도는 5점 만점에 4.48점으로 가장 높은 기호를 보였다. 또한 맛, 향, 질감 항목에서도 다른 요리에 비해 유의적으로 가장 높은 점수를 얻었다. '두릅곶감무침' 의 경우 외관 및 향, 질감, 전반적인 기호도에서 높은 점수를 보였으나 맛에서 다소 낮은 점수를 보였는데, 이는 소스로 사용된 바나나의 강한 단맛이 원인인 것으로 판단된다. 따 라서 주재료와 부재료의 적절한 조화를 통해 맛을 조절하되 같은 종류의 맛을 가지는 정미물질을 주재료와 부재료로 써서 맛의 상승작용이 역효과를 내지 않도록 하는 것이 바람직할 것으로 생각된다. '오가피순꽁치조림'은 '엄나무 순닭고기냉채'와 ‘두릅곶감무침'보다 낮은 기호를 보였으 나 모든 항목이 3점 이상으로 수용기준을 만족하였다. '참 죽만두'는 전체적인 기호도가 3.09점으로 햇순요리 중 가장 낮은 기호도를 보였으나 3.0 이상으로 만족 수준을 보였다. 또한 향에서 2.91점을 보여 가장 낮은 점수를 나타내었는데 이는 참죽의 특유한 향에 익숙하지 않아 거부감을 일으킨 것으로 판단된다. 따라서 향후 '참죽만두'는 부재료를 활용
하여 참죽의 향을 감쇄시킬 수 있는 방안을 강구해야 할 것으로 생각된다.

\section{햇순요리의 영양성}

엄나무순을 이용한 '엄나무순닭고기냉채', 두릅순을 이 용한 ‘두릅곶감무침', 오가피순을 이용한 '오가피순꽁치조 림' 및 참죽순을 이용한 ‘참죽만두’의 영양소 함량은 1 인분 을 한끼 당 영양권장량에 대한 영양소함량의 비율로 환산하 여 Table 4에 나타내었다.

'엄나무순닭고기냉채'의 열량은 $327.2 \mathrm{kcal}$ 로 권장량의 $37.8 \%$ 이었고, 단백질의 함량은 $18.3 \mathrm{~g}$ 으로 권장량 $(16.5 \mathrm{~g})$ 보다 높은 것으로 나타났다. 비타민 $\mathrm{A}$, 비타민 $\mathrm{E}$, 비타민 $\mathrm{B}_{6}$, 엽산의 함량이 각각 $20.1 \mathrm{~g}, 441.0 \mu \mathrm{g} \mathrm{RE}, 4.4 \mathrm{mg}, 0.7$ $\mathrm{mg}, 188.6 \mu \mathrm{g}$ 으로 권장량보다 높았다. 특히, 비타민 $\mathrm{A}$ 와 $\mathrm{E}$ 는 자유라디칼을 차단하는 천연 항산화제로 이들 함유 식품을 함께 섭취 시 단독 섭취 시에 비해 항산화 기능이 향상되며, 심혈관 질환, 암과 같은 만성질환의 위험성이 감소한다 $(25,26)$. 반면, 비타민 $\mathrm{C}$ 및 아연의 함량은 권장량 보다 낮았으나 각각 $83.6 \%, 63.4 \%$ 로 영 양소를 충족시키기 에 부족함이 없을 것으로 보이며, 이로 인한 항산화 및 면역 강화에도 도움을 줄 수 있을 것으로 판단된다(27).

두릅의 새순을 활용한 ‘두릅곶감무침'의 열량은 305.5 $\mathrm{kcal}$ 로 권장량의 $35.2 \%$ 이었고, 비타민 $\mathrm{E}$, 비타민 $\mathrm{C}$, 비타민 $\mathrm{B}_{6}$, 엽산 및 철의 함량은 각각 권장량의 $179.6 \%, 176.7 \%$, $122.4 \%, 157.2 \%, 140.6 \%$ 로 권장량보다 약 $1.2 \sim 1.7$ 배 정도 높았다. 비타민 C는 항산화비타민으로 잘 알려져 있으며 이와 같은 비타민을 섭취하였을 때 관상동맥질환을 예방하 고 치료하는데 효과가 있다는 연구 결과가 보고된 바 있다 (28). 엽산은 아미노산 대사와 핵산 합성에 필수적인 영양소 로 성장 발달 및 생식에 중요하며, 엽산이 결핍되면 거대적 아구성 빈혈이 나타나며, 특히, 임산부에서는 유산, 태반박 기 및 태아 신경관손상 등이 발생한다(29). 또한 철은 헤모 글로빈과 사이토크롬의 구성성분으로 산소의 운반과 저장 및 미토콘드리아의 전자전달에 관여함으로써 세포 호흡과 에너지 대사에 중요한 역할을 한다. 우리나라 가임기 여성 을 대상으로 엽산 섭취량을 조사한 결과, 섭취량은 45.6 65.8\%로 권장량에 크게 미달하여(30), 엽산 함유가

Table 3. Sensory properties of dishes using Haetsun sprouts

\begin{tabular}{lccccc}
\hline \multirow{2}{*}{ Dish } & \multicolumn{3}{c}{ Sensory characteristics } \\
\cline { 2 - 6 } & Appearance & Taste & Flavor & Texture & Overall preference \\
\hline Umnamusun -dakgoginaengchae & $4.24 \pm 0.93^{1 \mathrm{a} 2)}$ & $4.52 \pm 0.59^{\mathrm{a}}$ & $4.36 \pm 0.81^{\mathrm{a}}$ & $4.44 \pm 0.71^{\mathrm{a}}$ & $4.48 \pm 0.59^{\mathrm{a}}$ \\
Dureubgokgam -muchim & $4.16 \pm 0.75^{\mathrm{a}}$ & $3.88 \pm 1.20^{\mathrm{ab}}$ & $4.00 \pm 1.08^{\mathrm{ab}}$ & $4.12 \pm 0.73^{\mathrm{ab}}$ & $4.04 \pm 1.02^{\mathrm{ab}}$ \\
Ogapisun -Kkongchijolim & $3.50 \pm 0.90^{\mathrm{b}}$ & $3.42 \pm 1.16^{\mathrm{bc}}$ & $3.33 \pm 1.07^{\mathrm{bc}}$ & $3.67 \pm 1.07^{\mathrm{bc}}$ & $3.67 \pm 0.98^{\mathrm{bc}}$ \\
Chamjugmandu & $3.82 \pm 0.75^{\mathrm{ab}}$ & $3.09 \pm 0.83^{\mathrm{c}}$ & $2.91 \pm 0.70^{\mathrm{c}}$ & $3.55 \pm 0.52^{\mathrm{c}}$ & $3.09 \pm 0.70^{\mathrm{c}}$ \\
\hline
\end{tabular}

${ }^{1)}$ Means \pm SD ( $\left.=20\right)$.

${ }^{2)}$ Values in the column with different superscript letter are significantly different at $\mathrm{p}<0.05$. 
높은 식품의 섭취가 필요하다. 따라서 ‘두릅곶감무침'은 철분과 엽산의 함량이 풍부하여 빈혈 예방에 좋은 식품으로 판단된다.

'오가피순꽁치조림'은 단백질의 함량이 $27.6 \mathrm{~g}$ 으로 권장 량 $18.3 \mathrm{~g}$ 의 1.5 배에 해당하는 단백질 급원식품으로 볼 수 있다. 또한, 비타민 $\mathrm{A}$, 비타민 $\mathrm{E}$, 비타민 $\mathrm{C}$, 리보플라빈, 나이아신, 비타민 $\mathrm{B}_{6}$ 의 함량이 각각 $900.1 \mu \mathrm{g} \mathrm{RE}, 8.8 \mathrm{mg}$,
$73.2 \mathrm{mg}, 0.9 \mathrm{mg}, 10.4 \mathrm{mg}, 0.7 \mathrm{mg}$ 으로 권장량의 1.4 배에서 3.6 배에 해당하여 각종 비타민의 급원식품이라고도 할 수 있다. 특히, 비타민 $\mathrm{E}$ 는 권장량의 $221.2 \%$ 를 함유하고 있어 '오가피 순꽁치조림'은 우수한 비타민 $\mathrm{E}$ 의 급원식품으로 판단된다. 비타민 $\mathrm{E}$ 는 세포막에서 유리라디칼을 제거하며 지질과산화를 억제하고, 면역능력을 향상시키는데 효과가 있다(31). 뿐만 아니라 비타민 $\mathrm{D}$ 의 함량은 $19.0 \mu \mathrm{g}$ 으로 상한

Table 4. Nutrient composition of dishes using Haetsun sprouts

\begin{tabular}{|c|c|c|c|c|c|c|c|c|c|}
\hline \multirow[b]{2}{*}{ Nutrient composition } & \multirow{2}{*}{$\begin{array}{l}\text { Recommended } \\
\text { amount/meal } \\
\text { (A) }\end{array}$} & \multicolumn{2}{|c|}{$\begin{array}{c}\text { Umnamusun } \\
\text {-dakgoginaengchae }\end{array}$} & \multicolumn{2}{|c|}{ Dureubgokgammuchim } & \multicolumn{2}{|c|}{ Ogapisunkkongchijolim } & \multicolumn{2}{|c|}{ Chamjugmandu } \\
\hline & & $\begin{array}{l}\text { One serving } \\
\text { size (284 g) } \\
\text { (B) }\end{array}$ & $\begin{array}{c}\mathrm{B} / \mathrm{A} \times 100 \\
(\%)\end{array}$ & $\begin{array}{l}\text { One serving } \\
\text { size }(280 \mathrm{~g}) \\
\text { (C) }\end{array}$ & $\begin{array}{c}\mathrm{C} / \mathrm{A} \times 100 \\
(\%)\end{array}$ & $\begin{array}{l}\text { One serving } \\
\text { size (362 g) } \\
\text { (D) }\end{array}$ & $\begin{array}{c}\mathrm{D} / \mathrm{A} \times 100 \\
(\%)\end{array}$ & $\begin{array}{l}\text { One serving } \\
\text { size (408 g) } \\
\text { (E) }\end{array}$ & $\begin{array}{c}\mathrm{E} / \mathrm{A} \times 100 \\
(\%)\end{array}$ \\
\hline Energy (kcal) & 866.7 & 327.2 & 37.8 & 305.5 & 35.2 & 312.5 & 36.1 & 512.3 & 59.1 \\
\hline Carbohydrate (g) & - & 29.7 & - & 80.2 & - & 33.3 & - & 90.0 & - \\
\hline Fat $(\mathrm{g})$ & - & 15.4 & - & 0.9 & - & 11.0 & - & 7.2 & - \\
\hline Protein (g) & 18.3 & 20.1 & 109.4 & 7.4 & 40.5 & 27.6 & 150.3 & 25.1 & 136.8 \\
\hline Fiber (g) & - & 4.6 & - & 17.2 & - & 9.1 & - & 8.8 & - \\
\hline Ash (g) & - & 7.2 & - & 5.8 & - & 6.4 & - & 3.8 & - \\
\hline Vitamin A ( $\mu \mathrm{g}$ RE) & 250.0 & 441.0 & 176.4 & 93.4 & 37.4 & 900.1 & 360.0 & 869.8 & 347.9 \\
\hline Vitamin $\quad D(\mu g)$ & 1.7 & 0.0 & 0.0 & 0.0 & 0.0 & 19.0 & 1140.0 & 0.2 & 13.5 \\
\hline Vitamin E (mg) & 4.0 & 4.4 & 111.0 & 7.2 & 179.6 & 8.8 & 221.2 & 6.9 & 171.8 \\
\hline Vitamin $\mathrm{K}(\mu \mathrm{g})$ & - & 0.2 & - & 0.0 & - & 1.0 & - & 1.6 & - \\
\hline Vitamin C (mg) & 33.3 & 27.9 & 83.6 & 58.9 & 176.7 & 73.2 & 219.6 & 78.5 & 235.5 \\
\hline Thiamin (mg) & 0.4 & 0.3 & 85.7 & 0.2 & 58.6 & 0.2 & 50.0 & 0.6 & 149.1 \\
\hline Riboflavin (mg) & 0.5 & 0.4 & 82.2 & 0.4 & 71.7 & 0.9 & 180.5 & 0.3 & 69.3 \\
\hline Niacin (mg) & 5.3 & 4.2 & 79.4 & 3.7 & 69.0 & 10.4 & 195.3 & 2.2 & 40.7 \\
\hline Vitamin B6 (mg) & 0.5 & 0.7 & 141.5 & 0.6 & 122.4 & 0.7 & 149.2 & 0.4 & 73.9 \\
\hline Folic acid ( $\mu \mathrm{g})$ & 133.3 & 188.6 & 141.5 & 209.6 & 157.2 & 88.8 & 66.6 & 130.7 & 98.0 \\
\hline Vitamin B12 ( $\mu \mathrm{g})$ & - & 0.2 & - & 0.0 & - & 17.7 & - & 0.1 & - \\
\hline Pantothenic acid (mg) & - & 0.8 & - & 0.0 & - & 0.0 & - & 0.4 & - \\
\hline Biotin $(\mu \mathrm{g})$ & - & 0.0 & - & 0.0 & - & 0.0 & - & 3.0 & - \\
\hline Calcium (mg) & 250.0 & 83.6 & 33.4 & 49.3 & 19.7 & 262.6 & 105.0 & 173.4 & 69.3 \\
\hline Phosphorus (mg) & 233.3 & 218.8 & 93.8 & 195.5 & 83.8 & 383.0 & 164.1 & 303.4 & 130.0 \\
\hline Sodium (mg) & - & 1886.7 & - & 870.2 & - & 1225.0 & - & 413.5 & - \\
\hline Chlorine (mg) & - & 13.0 & - & 15.1 & - & 0.0 & - & 13.5 & - \\
\hline Potassium (mg) & - & 723.9 & - & 1560.7 & - & 1206.7 & - & 986.1 & - \\
\hline Magnesium (mg) & - & 9.1 & - & 0.0 & - & 0.0 & - & 25.9 & - \\
\hline Iron (mg) & 3.3 & 2.2 & 67.2 & 4.7 & 140.6 & 5.1 & 152.0 & 6.1 & 181.8 \\
\hline Zinc (mg) & 3.3 & 2.1 & 63.4 & 1.0 & 30.6 & 1.8 & 53.4 & 1.6 & 49.1 \\
\hline Cupper (mg) & - & 0.3 & - & 0.4 & - & 0.2 & - & 0.2 & - \\
\hline Manganese (mg) & - & 0.3 & - & 0.9 & - & 0.0 & - & 0.8 & - \\
\hline Iodine ( $\mu \mathrm{g})$ & - & 0.0 & - & 0.0 & - & 0.0 & - & 1.9 & - \\
\hline Selenium ( $\mu \mathrm{g}$ ) & - & 13.6 & - & 0.0 & - & 0.0 & - & 22.0 & - \\
\hline Cholesterol (mg) & - & 52.0 & - & 2.6 & - & 64.0 & - & 35.6 & - \\
\hline
\end{tabular}


섭취량인 $20 \mu \mathrm{g}$ 에 가까운 양이 함유되어 있어 우수한 비타 민 $\mathrm{D}$ 의 급원으로 확인되었다. 칼슘, 인 및 철의 함량은 각각 $262.6 \mathrm{mg}, 383 \mathrm{mg}$ 및 $5.1 \mathrm{mg}$ 으로 권장량의 $105.0 \%, 164.1 \%$ 및 $152.0 \%$ 으로 높았다. 또한 아연의 함량은 $1.8 \mathrm{mg}$ 으로 권장량의 $53.4 \%$ 로 나타나 권장량이 설정되어 있는 모든 무기질의 함량 또한 풍부한 것으로 확인되었다. 우리나라 국민건강영양조사에 따르면, 무기질 권장량에 대한 섭취비 율이 칼슘은 $71.0 \%$, 인은 $165.7 \%$, 철은 $95.2 \%$ 로 칼슘의 섭취량이 매우 낮음을 보였다(32). 또한 지역에 따른 성인의 무기질 섭취량을 조사한 결과, 권장량 대비 무기질 섭취비 율은 칼슘 $30.1 \%$, 인 $123.9 \%$, 철 $95.2 \%$, 아연 $73.1 \%$ 로 칼슘 과 아연의 섭취가 낮았다(33). 따라서 '오가피꽁치조림'은 비타민뿐만 아니라 칼슘을 비롯한 철, 아연의 함량이 높아 무기질의 우수한 급원식품으로 판단된다.

참죽의 새순을 이용한 '참죽만두’의 열량은 $512.3 \mathrm{kcal}$ 로 햇순나물 요리 중 가장 열량이 높게 나타났으며, 단백질의 함량도 $25.1 \mathrm{~g}$ 으로 권장량의 $136.8 \%$ 를 차지하였다. 항산화 활성을 가지는 비타민 $\mathrm{A}$, 비타민 $\mathrm{E}$, 비타민 $\mathrm{C}$ 의 함량이 각각 $869.8 \mu \mathrm{g} \mathrm{RE}, 6.9 \mathrm{mg}, 78.5 \mathrm{mg}$ 으로 권장량의 $347.9 \%$, $171.8 \%, 235.5 \%$ 를 차지하였다. 뿐만 아니라 '참죽만두'의 티아민 함량은 $0.6 \mathrm{mg}$ 으로 권장량의 $149.1 \%$ 를 차지하여, 다양한 비타민의 좋은 급원식품이 될 수 있을 것으로 판단 된다. 또한 철의 함량이 $6.1 \mathrm{mg}$ 으로 이는 권장량의 $181.8 \%$ 에 해당되어 항 빈혈식품으로 적합할 것으로 판단된다. 반 면에 리보플라빈, 나이아신, 비타민 $\mathrm{B}_{6}$, 칼슘, 아연은 권장 량의 $40 ~ 70 \%$ 정도로 낮았으나 엽산의 경우에는 권장량의 $98 \%$ 로 대부분 충족될 것으로 판단된다.

\section{요 약}

본 연구는 햇순나물의 이용성 증진 및 소비 촉진을 위하 여 햇순나물을 이용하여 4 종의 햇순요리를 개발하고 이들 의 관능적 특성 및 영양성을 평가하였다. 햇순요리에 대한 관능평가를 실시한 결과, 4 종의 햇순요리의 전반적인 기호 도가 3.0 이상으로 만족 수준이었으며, 그 중 '엄나무순닭고 기냉채'의 기호도는 5 점 만점에 4.48 점으로 가장 높은 기호 를 보였다. 엄나무 순을 이용한 ‘엄나무순닭고기냉채'는 단백질, 비타민 $\mathrm{A}$, 비타민 $\mathrm{E}$, 비타민 $\mathrm{B}_{6}$, 엽산의 함량이 권장량보다 높았으며, 비타민 $\mathrm{C}$ 및 아연의 함량은 권장량보 다 낮았으나 권장량의 $50 \%$ 이상은 충족하였다. 두릅의 새 순을 이용한 ‘두릅곶감무침'은 곶감과 함께 무쳐 두릅의 쓴맛과 떫은맛을 약화시켰으며, 비타민 $\mathrm{E}$, 비타민 $\mathrm{C}$, 비타 민 $\mathrm{B}_{6}$, 엽산 및 철의 함량이 권장량보다 약 1.2 1.7배 정도 높았다. 오가피 순을 이용한 '오가피순꽁치조림'은 무와 오가피순을 첨가하여 조리함으로써 꽁치의 비린내를 줄여 기호도를 높였다. ‘오가피순꽁치조림’은 단백질 함량이 권
장량의 1.5 배, 비타민 $\mathrm{A}, \mathrm{E}, \mathrm{C}$ 등 각종 비타민의 함량이 권장량의 1.4 3.6배 함유되어 있었다. 참죽순을 이용한 '참 죽만두’는 고기를 넣지 않고 두부와 각종 채소를 넣어 만들 었으며, 비타민 및 무기질이 풍부하고 다양한 영양소가 함 유되어 있었다. ‘참죽만두'는 햇순나물 요리 중 가장 열량이 높았으며, 비타민 A, 비타민 E, 비타민 C, 티아민, 인과 철의 함량이 권장량보다 높았다.

\section{감사의 글}

본 연구는 2014년도 농촌진흥청 특화작목연구개발과제 연구비 지원에 의하여 수행된 연구내용의 일부로 이에 감사 드립니다.

\section{References}

1. Min KH (2010) A study on the development of local foods and tourism merchandising in Gimje area. Korea Tourism Res Assoc, 24, 295-309

2. Quan S, Wang N (2004) Towards a structural model of the tourist experience: An illustration from food experiences in tourism. Tourism management, 25, 297-305

3. Min SH, Um JS, Oh IG (2005) Study on the perception and preference of the native local foods in Jecheon area J East Asian Soc Dietary Life, 15, 504-515

4. Kim MH, Jang HR, Yoon KY (2012) Changes in physicochemical properties of Haetsun vegetables by blanching. J Korean Soc Food Sci Nutr, 41, 647-654

5. Shin HJ, Jeon YJ, Shin HJ (2008) Physiological activities of extracts of Cedrela sinensis leaves. Korean J Biotechnol Bioeng, 23, 164-168

6. Song KE, Chae SC, Jun JE, Park WH, Chun BY, Joung HJ, Choi YS, Cho SH (2001) Antioxidant vitamin supplementation and levels of circulating cellular adhesion molecules. Korean J Clin Pathol, 21, 176-182

7. Cha JY, Ahn HY, Eom KE, Park BK, Jun BS, Cho YS (2009) Antioxidative activity of Aralia elata shoot and leaf extracts. J Life Sci, 19, 652-658

8. Im HJ, Jang HL, Jeong YJ, Yoon KY (2013) Chemical properties and antioxidant activities of the sprouts of Kalopanax pictus, Cedrela sinensis, Acanthopanax cortex at different plucking times. Korean J Food Preserv, 20, 356-364

9. Lee EB, Li DW, Hyun JE, Kim IH, Whang WK (2001) 
Anti-inflammatory activity of methanol extract of Kalopanax pictus bark and its fractions. J Ethnopharmacol, 77, 197-201

10. Choi HJ, Kim DH, Chung HS, Moon KD (2012) Food nutritional composition of castor aralia (Kalopanax pictus N) sprouts. Korean J Food Preserv, 19, 720-726

11. Park HJ, Nam JH, Jung HJ, Kim WB, Park KK, Chung WY, Choi JW (2005) In vivo antinociceptive, anti-inflammatory, and antioxidative effects of the leaf and stem bark of Kalopanax pictus in rats. Korean $\mathbf{J}$ Pharmacogn, 36, 318-323

12. Kwon TR, Kim SK, Min GG, Jo JH, Lee SP, Choi BS (1995) Seed germination of Aralia cordata thunb. and effect of mulching methods on yield and blanching. $\mathbf{J}$ Korean Soc Hort Sci, 36, 620-627

13. Lee SJ, Kim JM, Kwon OJ, Jeong YJ, Woo SC, Yoon KY (2011) Changes on quality of Acanthopanacis cortex and Aralia elata shoots by blanching conditions and thawing methods. Korean J Food Preserv, 18, 302-309

14. Kim SH, Jang SY, Jeong YJ (2012) Change in the quality characteristics of Acanthopanax and Cedrela shoot by salting conditions. Korean J Food preserv, 19, 501-509

15. Kim SH, Lee MH, Jeong YJ (2012) Quality characteristics of Cedrela sinensis shoot by soy sauce seasoning conditions. Korean J Food Preserv, 19, 873-881

16. Noh CH (1985) Practical Korean cooking. Hollym Corporation, Seoul, Korea.

17. Waters A (2010) The art of simple food: notes, lessons, and recipes from a delicious revolution. Clarkson Potter, New York, USA.

18. Wizenberg M (2009) A homemade life: stories and recipes from my kitchen table. Simon and Schuster, New York, USA.

19. Yoon ES (1996) Korean cooking. Hyoil, Seoul, Korea.

20. Kim SA, Kwon SJ (2004) Recipe standardization and nutrient analysis of native local foods in Gyeongsangnamdo region. J Korean Soc Food Sci Nutr, 33, 405-411

21. Connor WE (2000) Importance of $n-3$ fatty acids in health and disease. Am J Clin Nutr, 71S, 171-175

22. Singh G, Chandra R (1987) Biochemical and cellular effects of fish and fish oils. Prog Food Nutr Sci, 12,
371-419

23. Pyeun JH, Heu MS, Cho DM, Kim HR (1995) Proteolytic properties of cathepsin L, chymotrypsin, and trypsin from the muscle and viscera of anchovy, Engraulis japonica. J Korean Fish Soc, 28, 557-568

24. Lim YS, Jeong IH (2001) Development of conditioning for small red muscle fish using Kimchi seasoning ingredients and organic acids. J Korean Fish Soc, 34, 315-319

25. Bohm F, Edge R, Land EJ, Truscott TG (1997) Carotenoids enhance vitamin $\mathrm{E}$ antioxidant efficiency. J Am Chem Soc, 119, 621-622

26. Dieber-Rotheneder M, Puhl H, Waeg G, Striegl G, Esterbauer H (1991) Effect of oral supplementation with D-alpha-tocopherol on the vitamin E content of human low density lipoproteins and resistance to oxidation. J Lipid Res, 32, 1325-1332

27. Wintergerst ES, Maggini S, Hornig DH (2006) Immune-enhancing role of vitamin $\mathrm{C}$ and zinc and effect on clinical conditions. Ann Nutr Metab, 50, 85-94

28. Singh RB, Niaz MA, Rastogi SS, Rastogi S (1996) Usefulness of antioxidant vitamins in suspected acute myocardial infarction (The Indian experiment of infarct survival-3). Am J Cardiol, 77, 232-236

29. Hibbard BM (1993) Folate and feta development. Br J Obstet Gynaecol, 100, 307-309

30. Jin HO, Lim HS (2001) Major foods for folate and their folate contents of Korean child-bearing women. J Korean Soc Food Sci Nutr, 30, 152-158

31. Kim WK (1999) Effects of vitamin E supplementation on immune response and antioxidant defense parameters in healthy Korean elderly women. J Korean Soc Food Sci Nutr, 28, 924-933

32. Ministry of Health and Welfare (2002) Report on 2001 national health and nutrition survey (I). Ministry of Health and Welfare, Seoul, Korea.

33. Choi MK, Kim HS, Lee WY, Lee H, Ze KR, Park JD (2005) Comparative evaluation of dietary intakes of calcium, phosphorus, iron, and zinc in rural, coastal, and urban district. J Korean Soc Food Sci Nutr, 34, 659-666

(접수 2014년 6월 25일 수정 2014년 8월 13일 채택 2014년 8월 25일) 